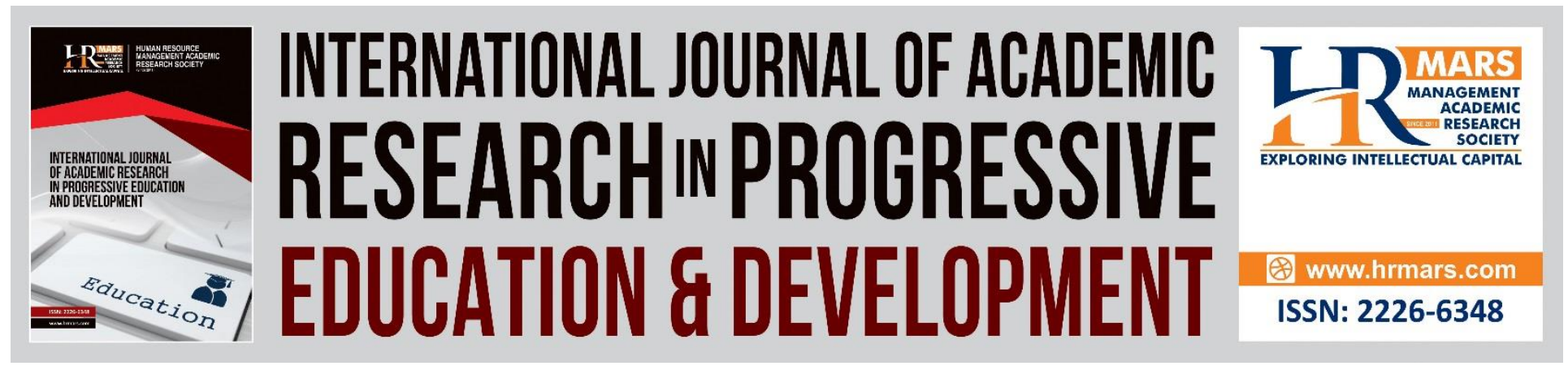

\title{
Generating Ideas for Writing Using Photography among Level 2 Rural Primary ESL Pupils
}

\section{Mading Ngalang, Hamidah Yamat}

To Link this Article: http://dx.doi.org/10.6007/IJARPED/v10-i1/8845

DOI:10.6007/IJARPED/v10-i1/8845

Received: 09 December 2020, Revised: 11 January 2021, Accepted: 31 January 2021

Published Online: 21 February 2021

In-Text Citation: (Ngalang \& Yamat, 2021)

To Cite this Article: Ngalang, M., \& Yamat, H. (2021). Generating Ideas for Writing Using Photography among Level 2 Rural Primary ESL Pupils. International Journal of Academic Research in Progressive Education and Development, 10(1), 392-405.

Copyright: (C) 2021 The Author(s)

Published by Human Resource Management Academic Research Society (www.hrmars.com)

This article is published under the Creative Commons Attribution (CC BY 4.0) license. Anyone may reproduce, distribute, translate and create derivative works of this article (for both commercial and non-commercial purposes), subject to full attribution to the original publication and authors. The full terms of this license may be seen at: $\underline{\text { http://creativecommons.org/licences/by/4.0/legalcode }}$

Vol. 10(1) 2021, Pg. 392 - 405

http://hrmars.com/index.php/pages/detail/IJARPED JOURNAL HOMEPAGE

Full Terms \& Conditions of access and use can be found at http://hrmars.com/index.php/pages/detail/publication-ethics 


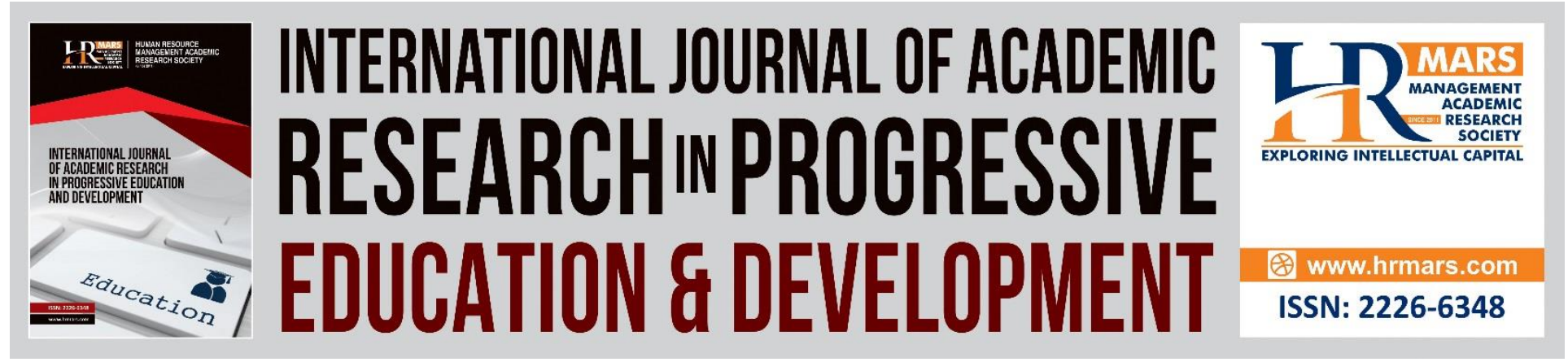

\title{
Generating Ideas for Writing Using Photography among Level 2 Rural Primary ESL Pupils
}

\author{
Mading Ngalang \\ SK Nanga Encheremin, D/A PPD Kapit, 96800 Kapit, Sarawak, Malaysia. \\ Email: madingngalang@gmail.com
}

Hamidah Yamat

Faculty of Education, National University of Malaysia (UKM), 43600 Bangi, Selangor, Malaysia.

Email: hamidah_yamat@ukm.edu.my

\begin{abstract}
Generating ideas for writing has always been considered difficult for rural primary school Malaysian pupils. Good ideas contribute to a good piece of writing. Hence, this quasiexperimental study was carried out to investigate the effect of using photography in idea generation among 13 Level 2 rural primary school pupils in Kapit, Sarawak. To achieve this aim, a pre-test and post-test were used to collect the data required. Besides, this study also aims to explore pupils' perception in using photography to generate ideas for writing. To achieve this aim, the data was collected through semi-structured interviewed and analysed using thematic analysis. The findings from the pre-test and post-test had shown an increase in the number of words written in the WH-template and their writing scores after the use of photography in idea generation. Besides, findings from the semi-structured interview had revealed that all participants have positive perceptions regarding the use of photography in their idea generation. This shows that photography has a positive effect in generating ideas for their writing.

Keywords: Idea Generation, Photography, Writing Difficulty, Writing Activity, Visual Literacy Tool

\section{Introduction}

Language learners, especially ESL pupils may face many problems in their English writing. Many studies had been conducted to explore the problems and challenges faced by the pupils in English writing. Moses and Mohamad (2019) listed some of the challenges faced by the pupils in writing are lack of vocabulary, poor grasp of grammar knowledge, inability to spell correctly, lack of motivation, students' readiness, and lack of exposure to English material. Students who learn English composition as a second or foreign language, faced many difficulties in terms of structural issues including choosing proper words, using correct grammar, generating ideas, and developing ideas about specific topics (Pek \& Mee, 2016).
\end{abstract}


In Malaysian primary school level, pupils are required to sit for the Primary School Achievement Test, which is also known as 'Ujian Pencapaian Sekolah Rendah' (UPSR) by the end of Year 6. In this examination, pupils' ability in constructing diverse written texts for different functions and purposes are assessed. According to len et al. (2017), English has been a difficult subject to UPSR candidates due to its writing component. Malaysian pupils, especially those from rural settings, are reported to have poor performance in their writing skills as compared to pupils who live in urban areas. Madut and Yunus (2017) stated that pupils in rural areas tend to struggle in writing as they hardly use English in everyday conversation and have limited exposure to English. English composition often becomes a problem for pupils as it involves various cognitive and linguistics strategies which they are uncertain (Maghsoudi \& Haririan, 2013). Hence, writing has become a challenging task for pupils, especially those who are from rural areas.

Other than that, len et al (2017) also stated that in writing, pupils' anxiety and uncertainty may lead to disorganisation of ideas. Even if they have the ideas, they may face difficulty in transforming the ideas into grammatically correct written form (len et al., 2017). However, writing goes beyond than using correct grammar or choosing proper words. It is also about writing down ideas and developing them effectively to attract readers' interest. Barreto (2006) claimed that students' confidence in writing ability need to be developed first, then attention can be given to correct grammar, punctuation, and spelling. According to Firmansyah (2015), pupils' inability to generate ideas is one of the major challenges faced by pupils in writing. Solagha (2013) also stated that pupils who have problem in generating ideas will often end up with negative thinking towards the actual writing. As a result, they could not perform well in their writing tasks. Hence, it is important to help pupils in generating ideas for writing.

The researcher's school is no exception. A preliminary study had been conducted to identify writing difficulties among Level 2 pupils in the school. The findings from the preliminary study revealed that pupils mostly faced difficulty in idea generation. In this study, the inability of pupils to generate their ideas in the $\mathrm{WH}$-question template had affected their quality of composition. Thus, making it harder for them to score well in the idea section based on the suggested marking scheme.

Therefore, this study aims to assist Level 2 primary school pupils in generating ideas through the use of photography which acts as an alternative option for visual literacy tool in teaching writing. This study is significant as it can be a starting point for pupils, particularly in rural areas, in changing their ways of generating ideas.

\section{Research Objectives}

The objectives of the study are:

1. To investigate the effect of using photography in idea generation for writing among rural Level 2 primary ESL pupils.

2. To explore the Level 2 rural primary ESL pupils' perception towards the use of photography in generating ideas for writing.

\section{Research Questions}

Based on the research objectives mentioned above, two research questions are raised:

1. What is the effect of photography in idea generation for writing? 
Vol. 10, No. 1, 2021, E-ISSN: 2226-6348 @ 2021 HRMARS

2. How do the Level 2 rural primary ESL pupils perceive the use of photography in generating ideas for writing?

\section{Literature Review}

Many studies had been done regarding the use of visual literacy in facilitating pupils' language learning. The concept of visual literacy is about using images, photos, or realia. It involves learners to analyse photographic images to understand them. Barreto (2006) stated that knowledge could be reinforced through the use of photographic image.

In order to take photography as visual literacy tool, there are two substantial procedures needed to be considered according to Barreto (2006). First, learners need to be taught to shoot and know the film process and second, they need to watch and explore the photos. The learners will observe the demonstration on how to shoot photos using the basic features in the smartphone cameras and then, generate ideas to describe the photos to their friends. Writing involves cognitive process. Colourful and meaningful stimulus helps learners in their writing. Barreto (2006) stated that individuals can develop visual competences when they see and think of personal experiences. The process in taking photos involves learners to communicate with the surroundings and their peers. As a result, this helps the learners in their idea generation.

Jackman (2003, as cited in Barreto, 2006) stated that photography is a great teaching tool for reluctant writers. Photography is a creative way to encourage students' participation in their writing processes. Pictures can be used by the pupils in the beginning of the process. Even the most reluctant writers might like the chance to write about a photo that is valuable to them.

\section{Methodology}

This study employed quasi-experimental research design 'One group pre and post-test'. 13 Level 2 rural primary pupils in Kapit, Sarawak were selected as participants through purposive sampling. In Malaysia, pupils in Year 4, Year 5 and Year 6 are considered as level 2 primary school pupils. They are within the age of 10 to 12 years old. The data for this study were collected through pre-test, post-test, and semi-structured interview.

\section{Pre-test \& Post-test}

The pre-test and post-test were administered to compare the difference in participants' competency to generate ideas and their writing scores before and after the use of photography. Data from pre-test and post-test were collected through the number of words written in WHTemplate and participants' writing scores. For this research, descriptive composition was selected. The time taken for the pre-test was 10-15 minutes during the while writing stage. The pupils were asked to begin their writing tasks by brainstorming the idea before writing the essays in a WH-questions template to jot down their ideas. The template consisted of questions like what, who, when, where, why and how. Once they had completed the WH-templates, they proceeded with their essay writing. Their compositions were collected and marked according to the marking scheme suggested by Teoh (2020), an excellent teacher award receiver. The full mark given for the composition is 25 marks. Besides, pupils' performance bands were also acknowledged. According to the marking scheme, pupils' scores are categorised as follow: 
Vol. 10, No. 1, 2021, E-ISSN: 2226-6348 @ 2021 HRMARS

Table 1. Writing scores and performances

\begin{tabular}{ll}
\hline Score & Performance \\
\hline $1-4$ & Limited \\
\hline $5-9$ & Satisfactory \\
\hline $10-15$ & Good \\
\hline $16-21$ & Excellent \\
\hline $22-25$ & Distinguished \\
\hline
\end{tabular}

\section{Semi-structured Interview}

Next, semi-structured interview was also carried out to understand how pupils perceive the idea of taking their own photos and using them as the tool to help them in idea generation. The questions were developed by the researcher and then checked by the research supervisor. The questions are as follow:

1. Do you like learning using photography?

2. Why do you like learning using photography?

3. How does photography help in generating ideas for writing?

4. What are the differences between learning to generate ideas using photography and learning using the usual method?

5. Do you want to continue using photography to generate ideas?

Table 2. Step and procedure in implementing photography to help pupils to generate ideas for writing

\begin{tabular}{|c|c|}
\hline Step & Procedure \\
\hline Step 1 & Pre-test: \\
\hline (Week 1) & - Descriptive topic was given. \\
\hline $26^{\text {th }}$ August 2020 & $\begin{array}{l}\text { - Participants were asked to jot } \\
\text { down their ideas in WH-Template. } \\
\text { - Participants wrote their essays. } \\
\text { - Grading }\end{array}$ \\
\hline \multirow{7}{*}{$\begin{array}{l}\text { Step } 2 \\
\text { (Week } 1-1^{\text {st }} \text { session) } \\
27^{\text {th }} \text { August } 2020\end{array}$} & $\begin{array}{l}\text { - Basic features in camera phones } \\
\text { were introduced: }\end{array}$ \\
\hline & 1) Brightness - Aperture (lighting) \\
\hline & $\begin{array}{l}\text { 2) Modes - Bokeh effect, Portrait, } \\
\text { Close-up, Panorama }\end{array}$ \\
\hline & $\begin{array}{l}\text { - Explain (with demonstration) how } \\
\text { to use the basic features in camera } \\
\text { phones. }\end{array}$ \\
\hline & $\begin{array}{l}\text { - Explain why pupils need the } \\
\text { strategy. }\end{array}$ \\
\hline & $\begin{array}{l}\text { - Pupils explored features in camera } \\
\text { phones. }\end{array}$ \\
\hline & $\begin{array}{l}\text { - Writing topic for next week was } \\
\text { given - 'My Best Friend.' }\end{array}$ \\
\hline Step 3 & - Pupils explored features in camera \\
\hline
\end{tabular}




\begin{tabular}{|c|c|}
\hline $\begin{array}{l}\text { (Week } 2-1^{\text {st }} \text { session) } \\
1^{\text {st }} \text { September } 2020\end{array}$ & $\begin{array}{l}\text { phones and took photo based on } \\
\text { the writing topic given during the } \\
\text { previous session. } \\
\text { Photos to be used during the next } \\
\text { session were printed out. }\end{array}$ \\
\hline $\begin{array}{l}\text { Step } 4 \\
\text { (Week } 2-2^{\text {nd }} \text { session) } \\
2^{\text {nd }} \text { September } 2020\end{array}$ & $\begin{array}{l}\text { Pupils wrote ideas in WH-Template } \\
\text { to write about the photos that they } \\
\text { took during the previous session. } \\
\text { Pupils wrote their descriptive } \\
\text { essay based on the ideas. } \\
\text { Writing topic for next week was } \\
\text { given - 'My Favourite Spot to Hang } \\
\text { Out.' }\end{array}$ \\
\hline $\begin{array}{l}\text { Step } 5 \\
\text { (Week } 3-1^{\text {st }} \text { session) } \\
8^{\text {th }} \text { September } 2020\end{array}$ & $\begin{array}{l}\text { - Pupils explored features in camera } \\
\text { phones and took photo based on } \\
\text { the writing topic given during the } \\
\text { previous session. } \\
\text { - Photos to be used during the next } \\
\text { session were printed out. }\end{array}$ \\
\hline $\begin{array}{l}\text { Step } 6 \\
\text { (Week } 3-2^{\text {nd }} \text { session) } \\
9^{\text {th }} \text { September } 2020\end{array}$ & $\begin{array}{l}\text { - Pupils wrote ideas in WH-Template } \\
\text { to write about the photos that they } \\
\text { took during the previous session. } \\
\text { - Pupils wrote their descriptive } \\
\text { essay based on the ideas. } \\
\text { Writing topic for next week was } \\
\text { given - 'My Class Morning Routine.' }\end{array}$ \\
\hline $\begin{array}{l}\text { Step } 7 \\
\text { (Week } 4-1^{\text {st }} \text { session) } \\
17^{\text {th }} \text { September } 2020\end{array}$ & $\begin{array}{l}\text { - Pupils explored features in camera } \\
\text { phones and took photo based on } \\
\text { the writing topic given during the } \\
\text { previous session. } \\
\text { - Photos to be used during the next } \\
\text { session were printed out. }\end{array}$ \\
\hline 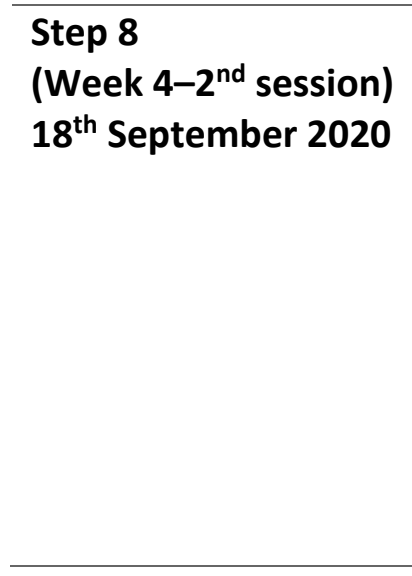 & $\begin{array}{l}\text { - Pupils wrote ideas in WH-Template } \\
\text { to write about the photos that they } \\
\text { took during the previous session. } \\
\text { Pupils wrote their descriptive } \\
\text { essay based on the ideas. } \\
\text { Writing topic for post-test was } \\
\text { given - 'My Favourite Food.' } \\
\text { At-home task: Pupils explored } \\
\text { features in their own camera } \\
\text { phones and took photo based on } \\
\text { topics given. }\end{array}$ \\
\hline
\end{tabular}


Vol. 10, No. 1, 2021, E-ISSN: 2226-6348 @ 2021 HRMARS

\begin{tabular}{|c|c|}
\hline Step 9 & Post-test \\
\hline (Week 5) & - Pupils wrote ideas in WH-Template \\
\hline $22^{\text {nd }}$ September 2020 & $\begin{array}{l}\text { and used the ideas to write about } \\
\text { the photos that they took during } \\
\text { the previous session. }\end{array}$ \\
\hline & $\begin{array}{l}\text { Pupils wrote their descriptive } \\
\text { essay based on the ideas. } \\
\text { - Grading }\end{array}$ \\
\hline
\end{tabular}

\section{Results and Discussion}

The findings of each data collection method are as shown below:

\section{Pre-test and Post-test}

\section{Number of Words Written in WH-Template}

Pupils' number of words written in the WH-Template before and after the use of photography in generating ideas were shown in Table 3.

Table 3. Participants' number of words written in the WH-Template before and after the use of photography in generating ideas

\begin{tabular}{cccc}
\hline $\begin{array}{c}\text { PARTICIPANTS } \\
\text { (Pseudonym) }\end{array}$ & $\begin{array}{c}\text { BEFORE } \\
\text { (words) }\end{array}$ & $\begin{array}{c}\text { AFTER } \\
\text { (words) }\end{array}$ & $\begin{array}{c}\text { INCREASE } \\
\text { (words) }\end{array}$ \\
\hline P1 & 11 & 31 & 20 \\
\hline P2 & 10 & 33 & 23 \\
\hline P3 & 15 & 36 & 21 \\
\hline P4 & 14 & 34 & 20 \\
\hline P5 & 8 & 20 & 12 \\
\hline P6 & 9 & 23 & 14 \\
\hline P7 & 10 & 29 & 19 \\
\hline P8 & 16 & 36 & 20 \\
\hline P9 & 8 & 22 & 14 \\
\hline P10 & 13 & 32 & 19 \\
\hline P11 & 10 & 31 & 21 \\
\hline P12 & 9 & 22 & 13 \\
\hline P13 & 7 & 17 & 10 \\
\hline
\end{tabular}

Based on the findings presented above, 6 participants managed to write 30 words and above in the WH-Template and 7 participants wrote between 29 words and below. Unlike before the implementation of photography, there was no participant wrote less than 10 words after the use of photography to generate ideas. With the use of photography, there is an increase in the number of words written in the WH-Template. The participants were able to write more words about the photographs that they took on their own. 
Vol. 10, No. 1, 2021, E-ISSN: 2226-6348 @ 2021 HRMARS

Therefore, the findings from this study support the study done by Ewald and Lightfoot (2002) which involves written production and photography among children from Africa and South Africa. The findings from the research concluded that children generated a lot of anecdotes in their lives using photograph. The research which includes a photography project allowed the participants to take their own pictures and write about them. It is revealed that the participants were able to express what they thought and felt by means of the writing skill. It indicates that photography helps in facilitating children in written production.

\section{Writing Scores}

As described in the methodology, pupils' writing scores were measured based on their ability to write ideas. The ability of pupils to generate their ideas in the WH-Template had affected the quality of their composition. In this study, the pupils wrote their descriptive essays based on the ideas or words written in the WH-Template. Pupils' scores for the Pre-Test and Post-Test were shown in Table 4.

Table 4. Pupils' writing scores before and after the use of photography in idea generation

\begin{tabular}{lllll}
\hline Participants & Pre-Test & Performance & Post-Test & Performance \\
\hline P1 & 10 & Satisfactory & 15 & Good \\
\hline P2 & 9 & Satisfactory & 15 & Good \\
\hline P3 & 13 & Good & 17 & Excellent \\
\hline P4 & 12 & Good & 17 & Excellent \\
\hline P5 & 7 & Satisfactory & 12 & Good \\
\hline P6 & 9 & Satisfactory & 14 & Good \\
\hline P7 & 9 & Satisfactory & 15 & Good \\
\hline P8 & 14 & Good & 20 & Excellent \\
\hline P9 & 6 & Satisfactory & 11 & Good \\
\hline P10 & 10 & Satisfactory & 15 & Good \\
\hline P11 & 8 & Satisfactory & 14 & Good \\
\hline P12 & 9 & Satisfactory & 13 & Good \\
\hline P13 & 6 & Satisfactory & 10 & Satisfactory \\
\hline & & & & \\
\hline
\end{tabular}

Based on the results, all participants showed an increase in their scores. Three participants managed to achieve an excellent performance, in which two of them scored 17 out of 25 marks and one participant scored 20. On the other hand, seven pupils managed to achieve good performance, in which three of them scored 15 out of 25 marks, two pupils scored 14, and another two participants scored 13 and 12, respectively. Meanwhile, there was only one participant that still achieved satisfactory performance. Although the participant did not manage to improve the writing performance band, the participant managed to show an improvement in term of scores, which is from 6 out of 25 marks to 10 marks in total.

The findings from this study reveal that photography helps in generating ideas by improving the participants' writing scores. The participants managed to score better in the idea section according to the marking scheme. The participants were able to generate more ideas in the $\mathrm{WH}$-Template and used them to write the composition. The improvement in their ability to 
generate ideas has impacted the quality of their composition. As a result, they were able to attain better scores. The findings from this study support the study done by Pek and Mee (2016) which involves the use of selfie photos in writing activity among university students. The findings from their study revealed that the treatment of using selfie photos in writing lessons had revealed a significant improvement in term of scores. This shows that the use of selfie photos has indicated to be an effective strategy in generating ideas for writing among the university students.

\section{Semi-structured Interview}

The semi-structured interview was conducted to assess how the use of photography helps the participants to generate ideas in their writing. The transcriptions were then analysed using thematic analysis. Five themes were identified by examining codes that the participants state most frequently. The participants' responses and the themes were shown in the table below:

Table 5. Thematic analysis of the semi-structured interview

\begin{tabular}{|c|c|c|c|}
\hline No. & Questions & Participants' response & Themes \\
\hline 1. & $\begin{array}{l}\text { Do you like } \\
\text { learning using } \\
\text { photography? }\end{array}$ & $\begin{array}{l}\text { (Yes.) } \\
\text { (Like.) } \\
\text { (I love.) }\end{array}$ & $\begin{array}{l}\text { Affective } \\
\text { attribute }\end{array}$ \\
\hline \multirow[t]{3}{*}{2.} & \multirow[t]{3}{*}{$\begin{array}{l}\text { Why do you } \\
\text { like learning } \\
\text { using } \\
\text { photography? }\end{array}$} & $\begin{array}{l}\text { (Excited) to use teacher's } \\
\text { phones. } \\
\text { (Excited) to take photos. } \\
\text { (Not boring) }\end{array}$ & $\begin{array}{l}\text { Affective } \\
\text { attribute }\end{array}$ \\
\hline & & $\begin{array}{l}\text { (My friends like the } \\
\text { photos that I took.) } \\
\text { (New experience.) }\end{array}$ & $\begin{array}{l}\text { Meaningful } \\
\text { learning }\end{array}$ \\
\hline & & $\begin{array}{l}\text { I can (move around with } \\
\text { friends). }\end{array}$ & Active learning \\
\hline \multirow[t]{3}{*}{3.} & \multirow{3}{*}{$\begin{array}{l}\text { How does } \\
\text { photography } \\
\text { help you in } \\
\text { generating } \\
\text { ideas for your } \\
\text { writing? }\end{array}$} & $\begin{array}{l}\text { (My photo is my story.) } \\
\text { (I took the photos.) }\end{array}$ & $\begin{array}{l}\text { Meaningful } \\
\text { learning }\end{array}$ \\
\hline & & (Not boring). & $\begin{array}{l}\text { Affective } \\
\text { attribute }\end{array}$ \\
\hline & & (Colourful photos). & $\begin{array}{l}\text { Colourful } \\
\text { stimulus }\end{array}$ \\
\hline \multirow[t]{2}{*}{4.} & \multirow{2}{*}{$\begin{array}{l}\text { What are the } \\
\text { differences } \\
\text { between } \\
\text { learning to } \\
\text { generate } \\
\text { ideas using } \\
\text { photography } \\
\text { and learning }\end{array}$} & $\begin{array}{l}\text { Usual lesson no phones } \\
\text { but (photography uses } \\
\text { phones). } \\
\text { I (use textbook) in usual } \\
\text { lesson. }\end{array}$ & Teaching tool \\
\hline & & $\begin{array}{l}\text { In photography, (I write } \\
\text { about the photos that I } \\
\text { took). }\end{array}$ & $\begin{array}{l}\text { Meaningful } \\
\text { learning }\end{array}$ \\
\hline
\end{tabular}


Vol. 10, No. 1, 2021, E-ISSN: 2226-6348 @ 2021 HRMARS

\begin{tabular}{llll}
\hline $\begin{array}{l}\text { using usual } \\
\text { method? }\end{array}$ & $\begin{array}{l}\text { Now, (my friends like my } \\
\text { story). }\end{array}$ & \\
\cline { 3 - 4 } & & $\begin{array}{l}\text { In usual lesson, (I don't } \\
\text { go outside). Now, I can. }\end{array}$ & Active learning \\
\hline $5 . \quad \begin{array}{l}\text { Do you want } \\
\text { to continue } \\
\text { learning using } \\
\text { photography } \\
\text { in future? }\end{array}$ & $\begin{array}{l}\text { Yes, because: } \\
\text { It is (fun.) }\end{array}$ & $\begin{array}{l}\text { Affective } \\
\text { (Not boring.) }\end{array}$ & attribute \\
\hline
\end{tabular}

\section{Theme 1: Affective attribute}

Based on the interview, participants showed positive affective attribute regarding the use of photography in generating ideas for writing. All participants stated that they like learning using photography, and they wanted to learn using it again in their future writing lesson. Yang (2012) stated that learning a new language through drilling and conventional way of teaching can be stressful for children. Thus, it is important to focus on lowering the affective filter when it comes to writing. Past research done by Pek and Mee (2016) mentioned that the use of selfie photos in writing activity has shown the ability to manipulate learners' motivation in communication and have provided opportunities for students to express themselves. In this study, learners were excited to explore the basic features in smartphone camera when taking photos. This indirectly has shifted their anxiety into doing something else. Hence, photography helps them in such a way it loosens the tension to write in English and at the same time, motivates them to write about something that is meaningful to them.

\section{Theme 2: Teaching tool}

Participants were excited to learn using phones as it is a new experience for them. The use of phones in classroom context allows them to take a break from textbooks. Past research done by Barreto (2006) who studies the effect of photography as a visual literacy tool stated that visual productions like photographs provide a new experience in the classroom and encourage learners to express opinions, emotions, and go about any image. In this study, the participants mentioned that learning using smartphones in a classroom context is a new experience to them. Thus, this evokes excitement among them.

\section{Theme 3: Meaningful learning}

From the interview, it is revealed that the participants preferred writing about topics that are familiar to them such as photos that are important to them. Familiar and personal subject matter can provoke scripts that children can use to generate writing (Bates 1991; Cleaver et al. 1993, as cited in Schweizer, 1999). In this study, some of the participants mentioned that they liked it when learning process allows them to write about the photos that they took and share with their peers. It is easy for them to do so as it was their own story that they were writing about. 
Vol. 10, No. 1, 2021, E-ISSN: $2226-6348$ @ 2021 HRMARS

\section{Theme 4: Active Learning}

From the interview, the participants like the idea of using photography in generating ideas for writing. They mentioned that by taking photographs, they had the chance to move around and interact with the surroundings. Moses and Mohamad (2019) stated that a successful writing activity requires active participants. Pupils can be involved actively in their learning when they are not only interacting with the surroundings but also have an interaction with their peers. The participants in this study were given chances to explore the basic features in smartphone cameras and write about the photographs that they took. This allows them to be involved actively in their learning.

\section{Theme 5: Colourful Stimulus}

Besides that, the participants also mentioned that the photographs that they took were colourful and thus, they liked it very much. Colours play an important role in learning process. Geigle (2014) stated that colours allow learners to remember information better. In photography, they will be writing about the colourful photos that they took. According to Langworth and Gardner (2010), one of many factors mentioned by them that contribute to learners' ability to remember and recall information is by associating the information with colours. The colourful photos provoke the participants to come out with details to describe the photos.

\section{Conclusion and Recommendations}

Findings from the pre-test and post-test has revealed significant improvement in the number of words written in the WH-Template and the writing scores. Apart from that, findings from the semi-structured interview have revealed that all participants have positive perceptions regarding the use of photography in their idea generation. This shows that photography has positive effects in generating ideas for their writing.

The study has important implications for ESL teachers, especially those who are teaching in rural areas. With restricted facilities and unconducive surroundings in the rural areas as claimed by len et al. (2017), learners are becoming more and more reliant on their teachers. Photography can become one of successful visual literacy tools in teaching writing. Hence, using photography in writing lesson can become a very interesting option for teachers who are teaching in rural areas as it promotes learners' interests and encourages them to write about the photos that they took.

In addition, this study also has significant implications to ESL learners, particularly those who are in rural areas. First, the use of photography in generating ideas allows learners to be actively involved in their learning and provides meaningful learning. They would be immensely involved in their writing task right from the start, in which they are given an opportunity to take their own photos based on the writing topics given. By doing so, they would have fun in exploring the basic features in camera phones such as the aperture and photography modes when taking photos. Hence, photography can be an interesting visual literacy tool for rural areas as it enables learners to take accountability of their learning. Most importantly, it is not just merely a photo, it is the photo that they took on their own. Jackman (2003, as cited in Barreto, 2006) even stated that photography does benefit the reluctant writers in such a way it provides confidence in their 
writing ability. Hence, photography can provide a better learning experience for learners, particularly passive and unwilling ones.

This study concluded that the use of photography triggers participants' ability in generating ideas for writing. Through the use of the right stimulus, to the like of photography in this study, learners may feel more committed to the writing task. Thus, giving them opportunities to generate as much as possible ideas for their writing.

Generating ideas for many is not an easy task. Krashen (1982) mentioned that affective factors such as anxieties and fear of making mistakes need to be lowered for learners to be more open to input. Pupils, especially primary ESL learners, need to be brave to write and not afraid of making mistakes because according to Krashen (1982), errors are inevitable and that learners in the early stages will make a lot of errors. Therefore, there is a need to motivate pupils to write. In order to do so, they need to write about things that interest them because according to Sahathevan and Yamat (2020), the teaching of writing should be accompanied with suitable strategies that have the ability to attract pupils' interest. For that reason, photography gives pupils the opportunity to do so by allowing them to take photos of their interest. Through the photographs, pupils will have the opportunity to express their ideas comfortably. With this study, teachers could apply photography as a pedagogical tool and photographs as instructional materials for their pupils during writing activities. Hence, this study could contribute as a startup in changing pupils' ways of generating ideas for their writing.

\section{Acknowledgement}

I would like to express my deepest sense of gratitude to the participants of this study. It is hoped that this study benefits them in generating ideas for their writing. My appreciation also goes to the administrators of SK Nanga Encheremin, Kapit, Sarawak who granted permission to the researcher to implement the use of photography in generating ideas for writing. To my supervisor, Associate Professor Dr. Hamidah binti Yamat, thank you for your guidance and help throughout the process of completing this research.

\section{References}

Barreto, S. L. C. (2016). Photography as a Visual Literacy

Tool. Colombian Applied Linguistics Journal, (8), 228. doi:10.14483/22487085.10514

Bates, L. (1991). The Effects on the Structure of Young Children

Written Narrative of Using a Sequence of Pictures or a Single Picture as a Stimulus. Literacy, 25(3), 2-10. doi:10.1111/j.1467-9345.1991.tb00033.x

Cleaver, B. E., Scheurer, P. E., \& Shorey, M. E. (1993). Children's Response to Silhouette Illustrations in Picture Books. Retrieved from https://eric.ed.gov/?id=ED370569

Ewald, W., \& Lightfoot, A. (2002). I Wanna Take Me a Picture:

Teaching Photography and Writing to Children. Beacon Press.

Firmansyah, A. (2015). The Influence of Mind Mapping Technique and

Students' Attitude toward Students' Ability in Writing a Recount Text of the Eighth Grade Students of State Junior High School 45 Palembang. Retrieved from https://jurnal.univpgri-palembang.ac.id/index.php/rip_didik/article/view/237 
INTERNATIONAL JOURNAL OF ACADEMIC RESEARCH IN PROGRESSIVE EDUCATION AND

DEVELOPMENT

Vol. 10, No. 1, 2021, E-ISSN: 2226-6348 @ 2021 HRMARS

Geigle, B. A. (2014). How Color Coding Formulaic Writing Enhances

Organization: A Qualitative Approach for Measuring Student Affect (Master's thesis, Humphreys College Graduate Faculty of the Graduate Studies Department, 2014). California: Stockton. Retrieved from https://eric.ed.gov/?id=ED554555.

Ien, L. K., Yunus, M. M., \& Embi, M. A. (2017). Build Me Up:

Overcoming Writing Problems Among Pupils in a Rural Primary School In Belaga, Sarawak, Malaysia. Jurnal Pendidikan Humaniora, 5(1), 1-7. doi:10.17977/um030v5i12017p001

Jackman, F. (2003). Reading, Writing, \& Digital Photography. Paper presented at by APTE Professional Education Development Group (p.3). Retrieved from http://www.portalcomunicacion.com.

Krashen, S. D. (1982). Principles and practice in second language acquisition. Oxford: Pergamon Press.

Langworth, R. M., \& Gardner, H. (2010). Multiple Intelligences. Retrieved from https://books.google.com/books/about/ Multiple_Intelligences.html?id=9hx7BZQApDYC

Madut, I. T., \& Yunus, M. M. (2016). Popsicle Simile: An Innovative Tool in Promoting Creative Writing among Rural Primary School ESL Learners. Retrieved from http://pasca.um.ac.id/ conferences/index.php/ice/article/view/57

Maghsoudi, M., \& Haririan, J. (2013). The Impact of Brainstorming Strategies Iranian EFL Learners Writing Skill Regarding their Social Class Status. International Journal of Language and Linguistics, 1(1), 60. doi:10.11648/j.ijll.s.20130101.20

Moses, R. N., \& Mohamad, M. (2019). Challenges Faced by Students and Teachers on Writing Skills in ESL Contexts: A Literature Review. Creative Education, 10(13), 3385-3391. doi:10.4236/ce.2019.1013260

Pek, L. S., \& Mee, R. W. (2016). Selfie: Engaging Life Experiences into Writing. Malaysian Journal of Distance Education, 17(2), 51-66. doi:10.21315/mjde2015.17.2.4

Sahathevan, E. N., \& Yamat, H. (2020). Learning Simple Sentence Construction Using Colourful Jenga Blocks. International Journal of Academic Research in Progressive Education and Development, 9(1), 1-14.

Schweizer, M. L. (1999). The Effect of Content, Style, and Color of Picture Prompts on Narrative Writing: An Analysis of Fifth and Eighth Grade Students' Writing (Doctoral dissertation, Faculty of the Virginia Polytechnic Institute and State University, 1999). Blacksburgh, Virginia: Virginia Tech. Retrieved from http://hdl.handle.net/10919/26243

Solagha, O. Z. (2013). Writing Difficulties in the Swedish ESLClassroom: How teachers of English deal with students' writing difficulties. Retrieved from https://www.semanticscholar.org/paper/Writing-Difficulties-in-the-Swedish-ESLClassroom-:-Solagha/ f1a8e7ed043d104122141dd7ce80e29affaffe3b

Teoh, P. (2020). Write it Right: Model Essays for UPSR Year 4, 5 and 6. Bangi, Selangor: Penerbitan Pelangi Sdn. Bhd. 


\section{INTERNATIONAL JOURNAL OF ACADEMIC RESEARCH IN PROGRESSIVE EDUCATION AND}

DEVELOPMENT

Vol. 10, No. 1, 2021, E-ISSN: 2226-6348 @ 2021 HRMARS

Yang, J. (2012). The affective filter hypothesis and its enlightenment for college English teaching. Psychology Research. 